\title{
THE RESPONSE OF BONE, CONNECTIVE TISSUE, AND MUSCLE TO ACUTE ACIDOSIS 1, 2
}

\author{
BY MARVIN F. LEVITT, LOUIS B. TURNER, AVRON Y. SWEET, AND \\ DEMETRA PANDIRI
}

(From the Departments of Medicine and Pediatrics, The Mount Sinai Hospital, New York City, N. Y.)

(Submitted for publication May 25, 1955 ; accepted September 21, 1955)

Previous evidence has indicated that under the influence of diverse stimuli, variable quantities of sodium, chloride, and water may be rapidly transferred into the fluid phase of the extracellular compartment (1-3). The precise source of these electrolytes has not been established. Since the tracer substances used to measure the fluid phase of the extracellular compartment (by the dilution technique) are excluded from the relatively solid phases of this compartment (bone and connective tissue), from the gastrointestinal tract and from cells (4-6), any one or combination of these sites could serve as a source of these electrolytes.

The possibility that the solid phase of the extracellular compartment may serve as an immediate reservoir of electrolytes is particularly intriguing since these solid phase tissues are characterized by excesses of specific electrolytes; sodium in the case of bone and presumably chloride in connective tissue $(7,8)$. It has recently been demonstrated that after two days of a combined stimulus of sodium depletion, chloride administration, potassium depletion and starvation, considerable quantities of sodium and potassium may be mobilized from rat bone $(9,10)$. It was not determined whether these electrolytes derived from cellular bone marrow or acellular bone cortex or possibly both sites. Furthermore that bone cortex per se may rapidly release considerable quantities of confined sodium and connective tissue release or alter the excess electrolytes contained therein to defend against an acute alteration in extracellular fluid composition has similarly not been established.

\footnotetext{
1 Presented in abstract form at the meeting of the American Society for Clinical Investigation at Atlantic City, N. J., May, 1954.

2 This investigation was supported in part by a grant from the Metabolic Institute of the National Institutes of Health, Public Health Service (A-277).
}

Accordingly, direct water and electrolyte analyses of marrow-free cortical bone and dense connective tissue (tendon) from the rat were performed to determine first, the quantities of electrolyte contained therein not attributable to extracellular fluid and second, whether these excesses might be rapidly mobilized by acute extracellular acidosis. Muscle and red cells were similarly analyzed to compare the response of such relatively cellular tissues with that of acellular solid phase extracellular tissues. The experiments were terminated four hours after the administration of a large ammonium chloride or hydrochloric acid load in order to define the extent to which endogenous redistribution of specific electrolytes preserved extracellular fluid composition prior to effective renal compensation.

\section{METHODS}

Normal male albino rats weighing 250 to 350 grams and maintained on a regular diet were injected intraperitoneally with one of two acid solutions. In the first group a solution of $100 \mathrm{mEq}$. per L. ammonium chloride was administered in amounts of $12 \mathrm{cc}$. per 100 grams of rat; in group number II, a $250 \mathrm{mEq}$. per L. solution of ammonium chloride or hydrochloric acid was injected in doses of $5 \mathrm{cc}$. per 100 grams of rat. The total chloride load administered was approximately equivalent in both groups but in group I, the administered solution was hypotonic whereas in group II a hypertonic solution was used. After the injection, the animals were placed in individual metabolism cages, fasted, and all urine formed was collected. Four hours after injection, the animals were lightly anesthetized with ether and immediately sacrificed by rapid exsanguination from the heart. Uninjected rats of similar size, maintained on the same diet and fasted for a comparable period, were sacrificed in the same way to serve as a control group. Plasma sodium, chloride, potassium and carbon dioxide concentrations, plasma $\mathrm{pH}$ and whole blood hematocrits were measured in the normal and acidotic rats. The volume of urine and residual peritoneal fluid as well as their respective electrolyte concentrations were also measured 
in the acidotic rats. Bone cortex, tendon, and muscle were analyzed for water, sodium, chloride, potassium, and calcium (in the case of bone) content in all rats.

Fragments of long bones were dissected from the lower extremities, and meticulously cleaned of adhering muscle and fat. All marrow was removed. Tendon was obtained from the tail and dissected free of adhering muscle or loose connective tissue. This latter procedure was performed in a cold, humid atmosphere to minimize loss of water from evaporation. Muscle was obtained from the lower extremities and quickly cleaned of visible fat and connective tissue. The tissues thus prepared were placed immediately in weighing bottles, minced, weighed, and the water content determined by drying to constant weight at $105^{\circ} \mathrm{C}$. The bone was ground to a very fine powder after a preliminary 24-hour period of drying and then dried further to constant weight.

The sodium and potassium content of bone, tendon, and muscle were determined by the wet digestion of dried finely ground aliquots of tissue in a 1:1 mixture of concentrated sulfuric acid and perchloric acid, subsequent dilution and analysis in a Baird Associates internal standard Flame Photometer. Calcium analyses of bone were performed by ashing a finely ground sample in a muffle furnace at $500^{\circ} \mathrm{C}$. for at least 48 hours and by subsequent precipitation of the calcium as calcium oxalate, according to the method of Bergstrom and Wallace (9). It has been previously contended that by the method of flame photometry, the presence of quantities of calcium found in bone may interfere with the sodium readings (11). Accordingly, known solutions of calcium and sodium containing quantities of these ions to be expected in these bone samples were subjected to this wet ashing technique and then analyzed for sodium content. No detectable influence on the sodium reading was apparent. Furthermore, the washed calcium-free supernatant from the dry ashed bone was analyzed for sodium and the results obtained from this dry ashing technique agreed with the sodium content determined by the wet ashing technique within 4 per cent. ${ }^{3}$ Accordingly, the sodium analyses were performed by the simpler wet ashing technique.

The chloride content of tendon and bone was measured by the nitric acid digestion technique as modified by Sunderman and Williams (12). Muscle chloride analyses were performed by the nitric acid extraction technique of Hastings and Eichelberger (13). Plasma, peritoneal fluid, urinary sodium and potassium concentrations were measured by flame photometry, similar chloride concentrations by the Volhard technique (14). Plasma $\mathrm{pH}$ measurements were made on a Beckman $\mathrm{pH}$ meter with proper correction for room temperature. Carbon dioxide content was measured by the method of Van Slyke and

\footnotetext{
3 The absence of any detectable calcium effect on the sodium readings probably relates to the fact that a city ordinance forbids the presence of propane tanks in hospitals. The considerably lower temperatures obtained in our photometer with city gas reduces the volatilization of the calcium and thereby eliminates its interfering effect.
}

Neill (15) and hematocrit by the standard Wintrobe tube. Insofar as relative changes after an acute stimulus were under study and as the animals were sacrificed by exsanguination, no corrections were made for fat content and blood contamination of muscle. The fat content and blood contamination of bone cortex and tendon of the rat are not significant.

Any conclusions regarding changes in the extracellular fluid of specific tissues studied are based upon the hypothesis that interstitial fluid or the fluid phase of the extracellular compartment bears an electrolyte composition identical to that of a serum ultrafiltrate. In this view, if all the sodium and chloride content of an organ is attributable to such fluid, the ratios of these ions should equal the ratios in serum ultrafiltrate. If one electrolyte is present in excess of the ratio found in serum, at least that amount in excess cannot be attributed to interstitial fluid. Under this same basic assumption, the volume of distribution of either sodium or chloride in any tissue, which ever be smaller, represents the maximal volume of interstitial fluid which that organ may contain.

\section{RESULTS}

The data on electrolyte and water content of the tissues from the normal rats are presented in Table I. Bone cortex contained approximately $0.29 \mathrm{mEq}$. of sodium per gm. of dry tissue, about $1 / 9$ th as much chloride or $0.03 \mathrm{mEq}$. of chloride per gm. of dry tissue and only trace quantities of potassium. The calcium content averaged $250 \mathrm{mg}$. per gm. of dry bone. Expressed in terms of calcium content, the amount of sodium in bone cortex averaged $1.15 \mathrm{mEq}$. per gm. of calcium. The sodium and chloride content of tendon were almost equivalent, averaging 1.91 and $1.99 \mathrm{mEq}$. per gm. of dry tendon, respectively. As in bone, the potassium content of tendon was extremely low. Muscle contained much larger quantities of potassium, averaging $0.411 \mathrm{mEq}$. of potassium per gm. of dry muscle, whereas the sodium and chloride content averaged 0.077 and $0.052 \mathrm{mEq}$. per gm., respectively. The mean water content of whole bone cortex, tendon and muscle equalled 18.1, 56.0 and 75.6 per cent, respectively. Plasma and red cell water electrolyte concentrations in the normal rat are included in Table I.

During the four-hour period of equilibration subsequent to the administration of the hypotonic ammonium chloride load in group I, approximately $2 / 3$ rds of the administered chloride was absorbed, the remaining peritoneal fluid becoming isosmotic with plasma. An average of $2.01 \mathrm{mEq}$. of chlo- 
TABLE I *

Normal rats (20)

\begin{tabular}{|c|c|c|c|c|c|c|}
\hline & Bone cortex & Tendon & Muscle & & Plasma & $\begin{array}{c}\text { Red blood } \\
\text { cells }\end{array}$ \\
\hline \multirow{2}{*}{$\begin{array}{l}\text { Sodium } \\
\text { (mEq./gm. of dry } \\
\text { tissue) } \\
\text { Std. Deviation } \\
\text { Std. Error } \dagger \\
\end{array}$} & .288 & .191 & .077 & $\begin{array}{l}\text { Sodium } \\
\text { (mEq./L.) }\end{array}$ & 142 & 15.3 \\
\hline & $\begin{array}{l}.013 \\
.003\end{array}$ & $\begin{array}{l}.008 \\
.002\end{array}$ & $\begin{array}{l}.007 \\
.002\end{array}$ & $\begin{array}{l}\text { Std. Deviation } \\
\text { Std. Error }\end{array}$ & $\begin{array}{l}4 \\
1\end{array}$ & $\begin{array}{l}3.0 \\
0.8\end{array}$ \\
\hline \multirow{2}{*}{$\begin{array}{l}\text { Chloride } \\
\text { (mEq./gm. of dry } \\
\text { tissue) } \\
\text { Std. Deviation } \\
\text { Std. Error } \\
\end{array}$} & .033 & .199 & .052 & $\begin{array}{l}\text { Chloride } \\
\text { (mEq./L.) }\end{array}$ & 106 & 55.3 \\
\hline & $\begin{array}{l}.006 \\
.002\end{array}$ & $\begin{array}{l}.008 \\
.002 \\
\end{array}$ & $\begin{array}{l}.004 \\
.001\end{array}$ & $\begin{array}{l}\text { Std. Deviation } \\
\text { Std. Error }\end{array}$ & $\begin{array}{l}4 \\
0.8\end{array}$ & $\begin{array}{l}5.5 \\
1.8\end{array}$ \\
\hline \multirow{2}{*}{$\begin{array}{l}\text { Potassium } \\
\text { (mEq./gm. of dry } \\
\text { tissue) } \\
\text { Std. Deviation } \\
\text { Std. Error }\end{array}$} & .02 & .03 & .411 & $\begin{array}{l}\text { Potassium } \\
\quad(\mathrm{mEq} . / \mathrm{L} .)\end{array}$ & 4.02 & 87.8 \\
\hline & & & $\begin{array}{l}.020 \\
.005\end{array}$ & $\begin{array}{l}\text { Std. Deviation } \\
\text { Std. Error }\end{array}$ & $\begin{array}{l}0.4 \\
0.1 \\
\end{array}$ & $\begin{array}{l}7.8 \\
2.6 \\
\end{array}$ \\
\hline \multirow{2}{*}{$\begin{array}{l}\text { Water } \\
\text { (\% of wet weight) } \\
\text { Std. Deviation } \\
\text { Std. Error }\end{array}$} & 18.1 & 56.0 & 75.6 & $\begin{array}{c}\text { Bicarbonate } \\
\text { (mEq./L.) }\end{array}$ & 28.0 & \\
\hline & $\begin{array}{l}1.5 \\
0.4\end{array}$ & $\begin{array}{l}1.7 \\
0.4\end{array}$ & $\begin{array}{l}0.4 \\
0.1\end{array}$ & $\begin{array}{l}\text { Std. Deviation } \\
\text { Std. Error }\end{array}$ & $\begin{array}{l}3.5 \\
1.0\end{array}$ & \\
\hline $\begin{array}{l}\text { Calcium } \\
\text { (mg./gm. of dry } \\
\text { bone) }\end{array}$ & 250.3 & & & $p H$ & 7.38 & $\begin{array}{l}\text { Hematocrit } \\
48 \%\end{array}$ \\
\hline $\begin{array}{l}\text { Std. Deviation } \\
\text { Std. Error }\end{array}$ & $\begin{array}{r}21.0 \\
5.0\end{array}$ & & & $\begin{array}{l}\text { Std. Deviation } \\
\text { Std. Error }\end{array}$ & $\begin{array}{l}0.07 \\
0.2\end{array}$ & \\
\hline
\end{tabular}

* The italicized data represent the mean figure for the entire group of rats.

$\dagger$ Standard error denotes standard error of the mean. Any two means which differ by more than two times the standard error are significantly different ( $p$ value less than .05 ).

ride was therefore transferred into the rat of which $0.61 \mathrm{mEq}$. was excreted in the urine (Table II). The net chloride gain averaged $1.39 \mathrm{mEq}$. in this group (Table II). Throughout the same period, an average of $1.87 \mathrm{mEq}$. of sodium was transferred into the peritoneal fluid and approximately $0.11 \mathrm{mEq}$. was lost in the urine. The net sodium loss averaged $1.97 \mathrm{mEq}$. (Table II). In this group, therefore, the acidotic stimulus included a net gain of about $1.39 \mathrm{mEq}$. of chloride and a net loss of $1.97 \mathrm{mEq}$. of sodium. In group II, subjected to the hypertonic acidotic stimulus,

TABLE II *

Acidotic stimuli

\begin{tabular}{|c|c|c|c|c|c|c|}
\hline \multirow[b]{2}{*}{$\begin{array}{l}\text { Group } \\
\text { No. }\end{array}$} & \multicolumn{3}{|c|}{$\begin{array}{c}\text { Sodium lost } \\
(m E q .)\end{array}$} & \multicolumn{3}{|c|}{$\begin{array}{c}\text { Chloride retained } \\
(m E q .)\end{array}$} \\
\hline & $\begin{array}{c}\text { Into } \\
\text { peri- } \\
\text { toneum }\end{array}$ & Urinary & Total & $\begin{array}{c}\text { From } \\
\text { peri- } \\
\text { toneum }\end{array}$ & $\begin{array}{c}\text { Urinary } \\
\text { loss }\end{array}$ & $\begin{array}{l}\text { Net } \\
\text { gain }\end{array}$ \\
\hline I & 1.87 & .11 & 1.97 & 2.01 & .61 & 1.39 \\
\hline II & 0 & .03 & .03 & 3.70 & .30 & 3.40 \\
\hline
\end{tabular}

* The italicized data represent the mean figure for the entire group of rats. the absorption of the administered chloride was virtually complete with no fluid remaining in the peritoneum after four hours. Accordingly, an average of $3.7 \mathrm{mEq}$. of chloride was transferred into the rat. The urinary chloride loss equalled $0.3 \mathrm{mEq}$. in this group, the net gain of chloride therefore averaging $3.4 \mathrm{mEq}$. (Table II). Virtually no sodium moved into the peritoneum in this group and the urinary sodium loss was barely detectable. The acidotic stimulus in group II therefore comprised almost entirely a net chloride gain of approximately $3.4 \mathrm{mEq}$. This amount equalled the combined chloride gain and sodium loss in group I.

In group I the net water gain averaged $5 \mathrm{cc}$., whereas, in group II, urine output was so low that the net water gain averaged $12 \mathrm{cc}$.

Both groups of acidotic rats revealed a comparable degree of acidosis as reflected in the fall of plasma $\mathrm{pH}$ to 7.17 and 7.19 , respectively (Tables III and IV). In group I the plasma electrolyte pattern was characterized by a $13 \mathrm{mEq}$. per L. or 9 per cent fall in the plasma sodium con- 
TABLE III *

Group I-Acidotic rats (18)-Hypotonic stimulus

\begin{tabular}{|c|c|c|c|c|c|c|c|c|c|c|c|}
\hline \multirow{3}{*}{$\begin{array}{l}\text { Sodium } \\
\text { (mEq./gm. of dry } \\
\text { tissue) } \\
\text { Std. Deviation } \\
\text { Std. Error } \dagger\end{array}$} & \multicolumn{2}{|c|}{ Bone cortex } & \multicolumn{2}{|c|}{ Tendon } & \multicolumn{2}{|c|}{ Muscle } & \multirow[b]{2}{*}{$\underset{\text { (mEq./L.) }}{\text { Sodium }}$} & \multicolumn{2}{|c|}{ Plasma } & \multicolumn{2}{|c|}{$\begin{array}{l}\text { Red blood } \\
\text { cells }\end{array}$} \\
\hline & .260 & $(.288)$ & .159 & $(.191)$ & .051 & $(.077)$ & & 129.0 & (142) & 12.8 & (15.3) \\
\hline & $\begin{array}{l}.013 \\
.003\end{array}$ & & $\begin{array}{l}.012 \\
.003\end{array}$ & & $\begin{array}{l}.005 \\
.001\end{array}$ & & $\begin{array}{l}\text { Std. Deviation } \\
\text { Std. Error }\end{array}$ & $\begin{array}{l}6.0 \\
1.2\end{array}$ & & $\begin{array}{l}3.5 \\
0.9\end{array}$ & \\
\hline \multirow{2}{*}{$\begin{array}{l}\text { Chloride } \\
\text { (mEq./gm. of dry } \\
\text { tissue) } \\
\text { Std. Deviation } \\
\text { Std. Error }\end{array}$} & .037 & $(.033)$ & .201 & $(.199)$ & .045 & $(.052)$ & $\begin{array}{l}\text { Chloride } \\
\text { (mEq./L.) }\end{array}$ & 107.0 & (106) & 64.8 & $(55.3)$ \\
\hline & $\begin{array}{l}.007 \\
.002 \\
\end{array}$ & & $\begin{array}{l}.013 \\
.003\end{array}$ & & $\begin{array}{l}.004 \\
.001\end{array}$ & & $\begin{array}{l}\text { Std. Deviation } \\
\text { Std. Error }\end{array}$ & $\begin{array}{l}7.0 \\
1.5\end{array}$ & & $\begin{array}{l}7.5 \\
2.0\end{array}$ & \\
\hline \multirow{2}{*}{$\begin{array}{l}\text { Potassium } \\
\text { (mEq./gm. of dry } \\
\text { tissue) } \\
\text { Std. Deviation } \\
\text { Std. Error }\end{array}$} & .03 & $(.02)$ & .03 & $(.03)$ & .415 & $(.411)$ & $\begin{array}{c}\text { Potassium } \\
(\mathrm{mEq} . / \mathrm{L} .)\end{array}$ & 4.9 & $(4.02)$ & 77.2 & $(87.8)$ \\
\hline & & & & & $\begin{array}{l}.02 \\
.005\end{array}$ & & $\begin{array}{l}\text { Std. Deviation } \\
\text { Std. Error }\end{array}$ & $\begin{array}{l}0.7 \\
0.2\end{array}$ & & $\begin{array}{l}5.5 \\
2.0\end{array}$ & \\
\hline \multirow{2}{*}{$\begin{array}{l}\text { Water } \\
\text { (\% of wet weight) } \\
\text { Std. Deviation } \\
\text { Std. Error }\end{array}$} & 17.9 & (18.1) & 56.0 & $(56.0)$ & 76.3 & $(75.6)$ & Bicarbonate & 12.2 & (28.0) & & \\
\hline & $\begin{array}{l}1.8 \\
0.4\end{array}$ & & $\begin{array}{l}1.5 \\
0.5\end{array}$ & & $\begin{array}{l}0.7 \\
0.15\end{array}$ & & $\begin{array}{l}\text { Std. Deviation } \\
\text { Std. Error }\end{array}$ & $\begin{array}{l}1.3 \\
0.4\end{array}$ & & & \\
\hline $\begin{array}{l}\text { Calcium } \\
\text { (mg./gm. of dry } \\
\text { bone) }\end{array}$ & 249.5 & $(250.3)$ & & & & & $p H$ & 7.17 & $(7.38)$ & $\underset{51 \%}{\text { Hem }}$ & $\begin{array}{l}\text { atocrit } \\
(48 \%)\end{array}$ \\
\hline $\begin{array}{l}\text { Std. Deviation } \\
\text { Std. Error }\end{array}$ & $\begin{array}{r}21.0 \\
5.0\end{array}$ & & & & & & $\begin{array}{l}\text { Std. Deviation } \\
\text { Std. Error }\end{array}$ & $\begin{array}{l}0.09 \\
0.03\end{array}$ & & & \\
\hline
\end{tabular}

* The data in italics represent the mean figure for the entire group of rats; the data in parentheses represent the mean data from the normal rats. † Standard error denotes standard error of the mean. Any two means which differ by more than two times the standard error are significantly different ( $p$ value less than .05 ).

centration, a fall of $16 \mathrm{mEq}$. per $\mathrm{L}$. in the bicarbonate concentration, but no change in the chloride concentration (Table III). In group II, the acidosis was characterized by an increase in the plasma chloride concentration of $9 \mathrm{mEq}$. per $\mathrm{L}$. or 9 per cent, a very slight fall in plasma sodium concentration, and a fall of about $8.5 \mathrm{mEq}$. per L. in the bicarbonate level (Table IV).
Despite the difference in the plasma electrolyte pattern between each acidotic group, namely a sodium bicarbonate deficiency in group $I$ as contrasted to a relative chloride excess in group II, the changes in the electrolyte content of bone and tendon in both these groups were very similar (Tables III and IV). The bone sodium content fell 10 and 9 per cent or 0.028 and $0.025 \mathrm{mEq}$., re-

TABLE IV *

Group II-Acidotic rats (12)-Hypertonic stimulus

\begin{tabular}{|c|c|c|c|c|c|c|c|c|c|c|c|}
\hline \multirow{3}{*}{$\begin{array}{l}\text { Sodium } \\
\text { (mEq./gm. of dry } \\
\text { tissue) } \\
\text { Std. Deviation } \\
\text { Std. Error } \dagger\end{array}$} & \multicolumn{2}{|c|}{ Bone cortex } & \multicolumn{2}{|c|}{ Tendon } & \multicolumn{2}{|c|}{ Muscle } & \multirow[b]{2}{*}{$\underset{\text { (mEq./L.) }}{\text { Sodium }}$} & \multicolumn{2}{|c|}{ Plasma } & \multicolumn{2}{|c|}{$\begin{array}{l}\text { Red blood } \\
\text { cells }\end{array}$} \\
\hline & .263 & $(.288)$ & .162 & (.191) & .058 & $(.077)$ & & 139 & (142) & 18.2 & (15.3) \\
\hline & $\begin{array}{l}.015 \\
.005\end{array}$ & & $\begin{array}{l}.005 \\
.002\end{array}$ & & .004 & & $\begin{array}{l}\text { Std. Deviation } \\
\text { Std. Error }\end{array}$ & $\begin{array}{l}9.0 \\
3.0\end{array}$ & & $\begin{array}{l}4.6 \\
1.5\end{array}$ & \\
\hline \multirow{2}{*}{$\begin{array}{l}\text { Chloride } \\
\text { (mEq./gm. of dry } \\
\text { tissue) } \\
\text { Std. Deviation } \\
\text { Std. Error }\end{array}$} & .038 & $(.033)$ & .196 & (.199) & .051 & $(.052)$ & $\begin{array}{l}\text { Chloride } \\
\quad(\mathrm{mEq} . / \mathrm{L} .)\end{array}$ & 115 & (106) & 63.2 & (55.3) \\
\hline & $\begin{array}{l}.006 \\
.002\end{array}$ & & $\begin{array}{l}.011 \\
.003\end{array}$ & & $\begin{array}{l}.002 \\
.0006\end{array}$ & & $\begin{array}{l}\text { Std. Deviation } \\
\text { Std. Error }\end{array}$ & $\begin{array}{l}7.0 \\
2.0\end{array}$ & & $\begin{array}{l}6.0 \\
2.0\end{array}$ & \\
\hline \multirow{2}{*}{$\begin{array}{l}\text { Potassium } \\
\text { (mEq./gm. of dry } \\
\text { tissue) } \\
\text { Std. Deviation } \\
\text { Std. Error } \\
\end{array}$} & .02 & (.02) & .03 & $(.03)$ & .411 & (.411) & $\begin{array}{c}\text { Potassium } \\
(\mathrm{mEq} . / \mathrm{L} .)\end{array}$ & & & 81.1 & $(87.8)$ \\
\hline & & & & & .025 & & $\begin{array}{l}\text { Std. Deviation } \\
\text { Std. Error }\end{array}$ & & & $\begin{array}{l}6.6 \\
2.2\end{array}$ & \\
\hline \multirow{3}{*}{$\begin{array}{l}\text { Water } \\
\text { (\% of wet weight) } \\
\text { Std. Deviation } \\
\text { Std. Error }\end{array}$} & 16.8 & (18.1) & 55.7 & $(56.0)$ & 77.0 & $(75.6)$ & Bicarbonate & 19.5 & $(28.0)$ & & \\
\hline & $\begin{array}{l}1.8 \\
0.6\end{array}$ & & $\begin{array}{l}0.8 \\
0.3\end{array}$ & & $\begin{array}{l}0.4 \\
0.2\end{array}$ & & $\begin{array}{l}\text { Std. Deviation } \\
\text { Std. Error }\end{array}$ & & & & \\
\hline & & & & & & & $\begin{array}{l}p H \\
\text { Std. Deviation } \\
\text { Std. Error }\end{array}$ & $\begin{array}{l}7.19 \\
0.07 \\
0.03\end{array}$ & (7.38) & $\begin{array}{l}\text { Her } \\
46 \%\end{array}$ & (48\%) \\
\hline
\end{tabular}

* The data in italics represent the mean figure for the entire group of rats; the data in parentheses represent the mean data from the normal rats. + Standard error denotes standard error of the mean. Any two means which differ by more than two times the standard error are significantly different ( $p$ value less than .05). 
spectively, in groups I and II with little change in chloride potassium or calcium content. Tendon sodium content fell 17 per cent and 15 per cent or 0.032 and $0.029 \mathrm{mEq}$. in groups I and II, respectively, without any apparent change in chloride or potassium content. The water content of these tissues did not change in the acidotic rats.

The changes in electrolyte content of muscle in groups I and II were not identical (Tables III and IV). Muscle sodium content fell 34 per cent or $0.026 \mathrm{mEq}$. in group I and 25 per cent or 0.019 mEq. in group II. The chloride content fell 15 per cent or $0.007 \mathrm{mEq}$. in group I but did not change in group II. No detectable changes from the normal were apparent in the potassium content of groups I and II. The water content, however, increased slightly in both acidotic groups. The changes in red cell water electrolyte composition are presented in Tables III and IV.

\section{DISCUSSION}

The ratio of $9 / 1$ for the sodium and chloride content of normal bone cortex when compared to the ratio of these ions in an ultrafiltrate of serum $(1: 2 / 1)$, indicates that at least 87 per cent of the bone sodium cannot be attributed to extracellular fluid and is probably confined by the bone cortex. Whether this considerable fraction of bone sodium is confined by the calcium (apatite) crystal or by the underlying protein matrix is not proved. It has been suggested that sodium is present as a double carbonate salt within the apatite crystal $(16,17)$. The very low potassium content of bone cortex and its well known sparsity of cells renders the possibility of cellular disposition for this excess sodium extremely unlikely. Compared to bone, dense connective tissue, as represented by tendon, contains a considerable quantity of chloride as well as sodium. Previous workers have concluded that a considerable fraction of tendon chloride cannot be attributed to its extracellular fluid phase $(7,8)$. In these data the ratio of chloride/sodium in tendon exceeds that of a plasma ultrafiltrate $(1.04 / .83)$ by approximately 25 per cent suggesting that at least 25 per cent of the total tendon chloride is confined by the underlying tissue. It is conceivable, however, that a fraction of the tendon sodium is also confined by the tissue matrix. Under this circumstance, the excess chloride of tendon would exceed 25 per cent of the total chloride content. That such is the case is suggested by dividing the sodium and chloride content of tendon by its water content. (Since water comprises 56 per cent of whole tendon (Table I), approximately $1.27 \mathrm{cc}$. of water is present per gm. of dry tendon.) This calculation yields a theoretical concentration of $150 \mathrm{mEq}$. per $\mathrm{L}$. of tendon water for sodium and $156 \mathrm{mEq}$. per L. for chloride. In so far as these concentrations exceed those of interstitial fluid by approximately 5 and 30 per cent, at least these fractions of the tendon sodium and chloride, respectively, cannot be attributed to interstitial fluid. If a fraction of tendon water is contained within cells or bound in some way and therefore removed from extracellular fluid, the percentage of sodium and chloride confined by this tissue would exceed these last mentioned figures. The trace quantities of potassium and the sparsity of cells in tendon suggest that these excess quantities of chloride and sodium are not confined within the few tendon cells but by the underlying protein matrix of the dense connective tissue.

The fall in bone sodium in acidotic groups $I$ and II, 0.028 and $0.025 \mathrm{mEq}$. per gm. of dry bone, respectively (Tables III and IV), far exceeds that fall which may have been anticipated from the change in extracellular fluid composition. In group I, the 9 per cent fall in plasma sodium concentration without any reduction in the chloride space of bone should have produced a maximal decrease in bone sodium content of about 0.003 mEq. per gm. In group II, no distinct change in plasma sodium concentration or in chloride space of bone was evident. Accordingly, it may be concluded that the acidotic stimulus in each group effected a transfer of $0.025 \mathrm{mEq}$. of sodium per gm. of dry bone into the extracellular fluid (Figure 1). This transfer occurred without any detectable change in bone calcium or water content in group I and with only a very slight, probably insignificant fall, in bone water in group II (Tables III and IV).

Assuming that all of the tendon sodium is attributable to the extracellular fluid of tendon, a fall of 9 per cent in plasma sodium concentration should have produced in the group I rats a proportionate fall in tendon sodium content, or a fall of $0.017 \mathrm{mEq}$. per gm. The reduction observed, however, averaged $0.032 \mathrm{mEq}$. almost twice the expected fall (Table III). In group II, the 8 


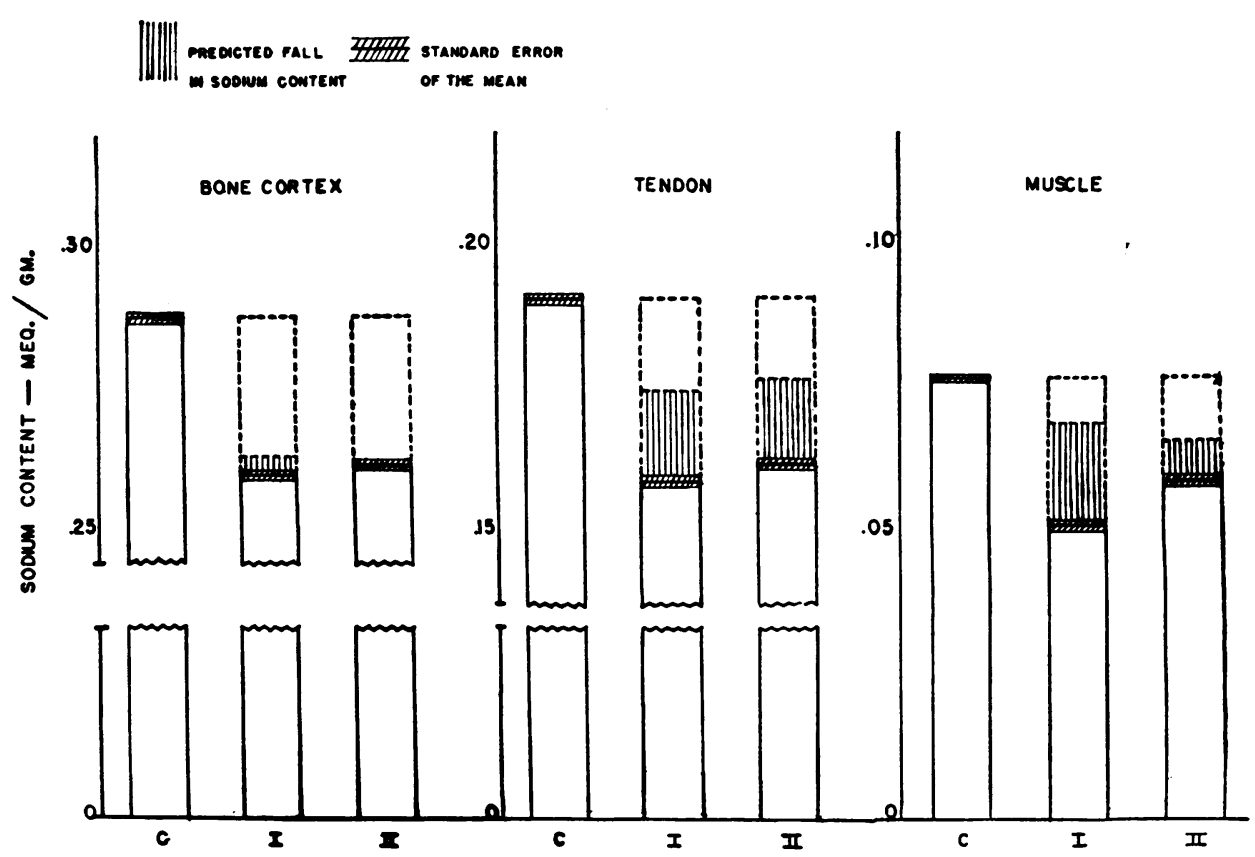

Fig. 1. A Graphic Representation of the Fall in Tissue Sodium after Acute AcIDosis

The shaded area represents the expected fall in tissue sodium. The clear area denotes that quantity of sodium per gm. of dry tissue transferred into the fluid phase of the extracellular volume.

per cent increase in plasma chloride concentration without any change in tendon chloride content presumably reflects a proportionate decrease in extracellular phase of tendon. Based upon the above mentioned assumption, such a fall in extracellular fluid volume should have produced a comparable reduction in tendon sodium content, of $0.015 \mathrm{mEq}$. per gm. As in group I, however, the observed decline, $0.029 \mathrm{mEq}$. was twice that anticipated on this premise. These excessive falls in tendon sodium are not compatible with the assumption that the sodium content of tendon is entirely attributable to its content of extracellular fluid. Instead these data in the acidotic rats suggest, as do the comparisons of the sodium and water content of normal rat tendon, that at least 7 to 8 per cent of tendon sodium, about $0.015 \mathrm{mEq}$. per gm. of dry tendon is confined in the tissue matrix of tendon and may be released to the extracellular fluid after an appropriate stimulus (Figure 1). The sole alternate explanation for this excessive drop in tendon sodium content would demand a considerable undemonstrated reduction in extracellular fluid volume of dense connective tissue. The absence of a coincidental and consistent fall in tendon water or chloride content renders this view unlikely.

The falls in muscle sodium content, namely 34 and 25 per cent, or 0.026 and $0.019 \mathrm{mEq}$. per gm. in acidotic groups I and II, respectively (Tables III and IV), are best explained by a combination of changes. In both groups, a distinct fall in extracellular volume of muscle, as measured by the chloride space, was detected. In group I this decrease averaged 13 per cent (a 13 per cent fall in muscle chloride content without change in plasma chloride concentration); in group II, it averaged 8 per cent (an increase in plasma chloride concentration of 8 per cent without change in muscle chloride content). In group I an additional 9 per cent fall in muscle sodium content may be attributed to the reduced plasma sodium concentration. The falls in muscle sodium content, however, exceeded that attributable to the changes in the extracellular fluid of muscle by about 12 per cent or $0.009 \mathrm{mEq}$. per gm. in group I and 17 per cent or $0.013 \mathrm{mEq}$. per gm. in group II (Figure 1). It may be concluded that approximately $0.011 \mathrm{mEq}$. of sodium per gm. of dry muscle was transferred out of cells by these acidotic stimuli. 
Such a transfer involving 75 per cent of total intracellular sodium content was not associated in these experiments with a detectable increase in the muscle potassium content. While it is conceivable that the quantity of potassium transferred was proportionately too small to be measured, it is possible that the fall in cellular sodium content may best be explained as a direct exchange of extracellular hydrogen for intracellular sodium.

The fall in the chloride space and presumably extracellular phase of muscle of the acidotic rats coexistent with a slight increase in total muscle water suggested that the intracellular volume had expanded. The cause of these reciprocal changes in extracellular and intracellular volume following the production of acute extracellular acidosis is not certain. It has previously been suggested that a fall in the $\mathrm{pH}$ of red cells increases the cellular osmotic pressure and draws water into the cells (18). The presence of such a phenomenon in muscle cells would best explain the simultaneous reduction in extracellular volume and expansion of intracellular volume.

The stimulus responsible for the transfer of sodium out of bone cortex, dense connective tissue and muscle appeared to be the consistent fall in plasma $\mathrm{pH}$, reflecting a state of severe decompensated acidosis. The alternate stimuli including a negative sodium balance, reduced plasma sodium concentration, increased plasma chloride concentration, or a marked fall in bicarbonate concentration were not consistently present in both acidotic groups. For reasons mentioned above it is unlikely that the sodium derived from bone and tendon came from cellular sources. It is probable that a fall in extracellular $\mathrm{pH}$ so alters the underlying protein matrix or the apatite crystal of bone as to effect a release of the confined sodium. That such a change in $\mathrm{pH}$ might similarly affect the protein molecules in muscle cells also seems feasible.

The relative amounts of sodium released 0.025 $\mathrm{mEq}$., $0.015 \mathrm{mEq}$., and $0.010 \mathrm{mEq}$. per gram of bone, tendon and muscle, respectively, also appear relevant (Figure 1). If it be assumed that comparable changes occur in man after a comparable stimulus bone, connective tissue, and muscle cells would release 175,75 and $70 \mathrm{mEq}$., respectively, to the fluid phase of the ECV.

Presuming that changes in the over-all chloride space serve as an index of changes in extracellu- lar volume, the positive chloride balance should have reflected an increase in extracellular volume of about $15 \mathrm{cc}$. and $30 \mathrm{cc}$. in groups I and II, respectively. Insofar as the extracellular fluid of rats approximates 20 per cent of body weight or about $60 \mathrm{cc}$. in a $300 \mathrm{gm}$. rat, these changes should have augmented the extracellular volume by 25 and 50 per cent. No such expansion of the chloride space was detected in any of the tissues studied: in fact, the chloride space of muscle actually fell. While it is possible that some over-all expansion of the extracellular fluid occurred despite the discrepant changes in the tissues studied and without a fall in hematocrit, it is likely that considerable quantities of chloride may have been confined in the solid protein matrix or cells of specific tissues (19). Viscera, loose connective tissue and gastrointestinal tract may, for example, have removed large quantities of chloride from the interstitial fluid. Whatever the precise disposition of this "lost chloride," it may be concluded that an over-all expansion of the chloride space may not necessarily indicate a comparable expansion of extracellular volume and need not be reflected in any individual tissue-even one present in such large mass as muscle. Conversely, conclusions drawn from changes in the chloride space of muscle may not be applied to the organism as a whole.

The quantities of sodium confined in bone and tendon with relatively little water and the release of considerable fractions of this base without any detectable changes in water content suggest that the osmotic activity of the confined sodium is considerably reduced. Upon transfer to the free extracellular fluid the osmotic work produced by these ions may be considerably enhanced.

These data further support the contention that the extracellular compartment comprises several heterogeneous phases rather than one homogeneous solution. In addition to the fluid phase or interstitial fluid with uniform electrolyte composition, there are collections of trans-cellular fluids (20) with varying electrolyte compositions: i.e., cerebrospinal fluid, ocular fluid, gastrointestinal juices. Furthermore there exist relatively solid phases composed primarily of protein matrix which are interspersed throughout the interstitial fluid and are concentrated in characteristic sites such as bone and connective tissue. These solid phase tissues appear capable of con- 
fining variable quantities of sodium and chloride (21). Such electrolytes, as in the case of sodium in these experiments, may be rapidly released by extreme changes in the composition of the interstitial fluid. The circumstance that the various extracellular phases respond in a heterogeneous and discrepant fashion to a single stimulus precludes the possibility that a single ion or molecule can distribute itself homogeneously throughout the entire extracellular compartment and thereby afford a precise measure of its total volume. At best, such tracer substances provide an index of the volume of the fluid phase or interstitial fluid.

\section{SUMMARY AND CONCLUSIONS}

1. Electrolyte analyses of bone cortex, tendon, and muscle from the normal rat reveal the following composition. Bone cortex contains 0.288 $\mathrm{mEq}$. of sodium, $0.033 \mathrm{mEq}$. of chloride and 0.02 $\mathrm{mEq}$. of potassium per gm. of dry tissue; tendon $0.191 \mathrm{mEq}$. of sodium, $0.199 \mathrm{mEq}$. of chloride and $0.03 \mathrm{mEq}$. of potassium per gm. of dry tissue; and muscle $0.077 \mathrm{mEq}$. of sodium, $0.052 \mathrm{mEq}$. of chloride and $0.411 \mathrm{mEq}$. of potassium per gm. of dry tissue. The water content of whole bone cortex, tendon, and muscle averages 18.1 per cent, 56 per cent and 75.6 per cent, respectively.

2. These data indicate that approximately 87 per cent of bone sodium, at least 7 per cent of tendon sodium and 33 per cent of tendon chloride, and approximately 20 per cent of muscle sodium cannot be attributed to the extracellular fluid content of these tissues.

3. Severe acute extracellular acidosis mobilizes $0.025 \mathrm{mEq}$., $0.015 \mathrm{mEq}$. and $0.010 \mathrm{mEq}$. of sodium per gm. of tissue from the non-extracellular fluid stores of bone, tendon, and muscle, respectively.

4. Acute acidosis evokes a reduction in extracellular volume and a coexistent expansion of intracellular volume in muscle.

\section{REFERENCES}

1. Levitt, M. F., and Bader, M. E., Effect of cortisone and ACTH on fluid and electrolyte distribution in man. Am. J. Med., 1951, 11, 715.

2. Katcher, A. L., Levitt, M. F., Sweet, A. Y., and Hodes, H. L., Alterations of fluid and electrolyte distribution and renal function in diarrhea of infancy. J. Clin. Invest., 1953, 32, 1013.

3. Levitt, M. F., Turner, L. B., and Sweet, A. Y., The effect of experimental venous obstruction on salt and water distribution and excretion in man. $J$. Clin. Invest., 1952, 31, 885.
4. Turner, L. B., and Levitt, M. F., The extracellular compartment: a comparison of the chloride and inulin spaces. J. Mt. Sinai Hosp., 1953, 19, 653.

5. Cotlove, E., Mechanism and extent of distribution of inulin and sucrose in chloride space of tissues. Am. J. Physiol., 1954, 176, 396.

6. Levitt, M. F., and Gaudino, M., Measurement of body water compartments. Am. J. Med., 1950, 9, 208.

7. Harrison, H. E., Darrow, D. C., and Yannet, H., The total electrolyte content of animals and its probable relation to the distribution of body water. J. Biol. Chem., 1936, 113, 515.

8. Manery, J. F., and Hastings, A. B., The distribution of electrolytes in mammalian tissues. J. Biol. Chem., 1939, 127, 657.

9. Bergstrom, W. H., and Wallace, W. M., Bone as a sodium and potassium reservoir. J. Clin. Invest., 1954, 33, 867.

10. Bergstrom, W. H., The participation of bone in total body sodium metabolism in the rat. J. Clin. Invest., 1955, 34, 997.

11. Wallace, W. M., Holliday, M., Cushman, M., and Elkinton, J. R., The application of the internal standard flame photometer to the analysis of biologic material. J. Lab. \& Clin. Med., 1951, 37, 621.

12. Sunderman, F. W., and Williams, $P$., The analysis of chloride in tissues. J. Biol. Chem., 1933, 102, 279.

13. Hastings, A. B., and Eichelberger, L., The exchange of salt and water between muscle and blood. I. The effect of an increase in total body water produced by the intravenous injection of isotonic salt solutions. J. Biol. Chem., 1937, 117, 73.

14. Whitehorn, J. C., Concerning chloride determinations by the modified Volhard titration. J. Biol. Chem., 1927, 74, 299.

15. Van Slyke, D. D., and Neill, J. M., The determination of gases in blood and other solutions by vacuum extraction and manometric measurement. I. J. Biol. Chem., 1924, 61, 523.

16. Gabriel, S., Chemische Untersuchungen über die Mineralstoffe der Knochen und Zähne. HoppeSeyler's Ztschr. f. physiol. Chem., 1894, 18, 257.

17. Kaltreider, N. L., Meneely, G. R., Allen, J. R., and Bale, W. F., Determination of the volume of the extracellular fluid of the body with radioactive sodium. J. Exper. Med., 1941, 74, 569.

18. Peters, J. P., Body Water; The Exchange of Fluids in Man. Springfield, Ill., Charles C Thomas, 1935.

19. Pitts, R. F., Mechanisms for stabilizing the alkaline reserves of the body. Harvey Lectures 1952-3, p. 172.

20. Edelman, I. S., Olney, J. M., James, A. H., Brooks, L., and Moore, F. D., Body composition: Studies in the human being by the dilution principle. Science, 1952, 115, 447.

21. Meyer, K., and Rapport, M. M., The mucopolysaccharides of the ground substance of connective tissue. Science, 1951, 113, 596. 